\title{
Enhancement of Cumin (Cuminum cyminum L.) Productivity Using Some Natural Plant Extracts
}

\author{
Hemat S. Abd El-Salam, Abeer A. Dahab and M.F. Mohamed \\ Medicinal and Aromatic Plant Research Department, \\ Horticulture Research Institute, Agricultural Research Centre, \\ Cairo, Egypt.
}

\begin{abstract}
T N THE present study, the effect of garlic (Allium sativum) and onion (Allium cepa) essential oils and water extracts at three concentrations $(5,10$ and $15 \%)$ on yield and chemical composition of cumin (Cuminum cyminum L.) were investigated. All treatments improved growth parameters (plant height, shoot number and number of umbels /plant) and total seed yield with no effect on the chemical composition of cumin essential oil. Onion water extracts gave the highest total seed yield. Garlic water extracts gave the highest values of total carbohydrate, total protein and total free amino acids. The chemical composition of essential oils extracted from garlic cloves and onion bulbs were fractionated by GC/MS. Major compounds in garlic were allicin and diallyl disulfide followed by dimethyl-trisulfide while in onion were allium thiosulfinate, alkyl thiosulfnates and allyl propyl disulphide.
\end{abstract}

The use of natural products in horticultural practices instead of synthetic chemicals is becoming a main target for many fruit crop producers, where the world market has been growing rapidly in recent years for organic fruit production (Dimitri and Oberholtzer, 2006). Over the next few years, organic products will increase by $15-20 \%$ per year (Kortbech-Olesen, 2006), creating an opportunity to motivate agricultural producers to adopt organic concept to cultivate medicinal, aromatic plants and vegetables, thus obtaining the benefit of premium prices. Onion (Allium cepa L.) and garlic (Allium sativum L.), the most well-known species belonging to the allium family and commonly used in our daily diet, have been studied extensively for their therapeutic uses as antibiotic, antidiabetic, antiatherogenic and anticancer drugs (Augusti, 1996). Many of these biological effects are related to volatile sulphides, typical of the alliumplants, which are also responsible for their characteristic pungent aroma and taste (Lanzotti, 2006). Allicin (allyl 2-propene thiosulfinate or Diallylthiosulfinate was long thought to be the principal bioactive compound present in aqueous extract or raw garlic homogenate (Augusti, 1975).Important sulfur-containing compounds present in garlic homogenate are allyl methyl thiosulfonate, 1-propenyl allylthiosulfonate and -L-glutamyl-S-alkyl-L-cysteine (Block,1985). Sulfur compounds can induce bud breaking continues to be unknown. However, progress has been made in elucidating the implied routes in the regulation of sulfur in relation to the vegetative growth of plants (Hawkesford and De Kok, 2006). The sulfur demand of the genus allium is 
related to the synthesis of thiosulfinates (Block et al., 1992). In the case of onion, the content of thiosulfinates increased linearly with the sulfur supply which makes this species a good candidate for desulfurization of a sulfur enriched soil (Randle et al., 1994).

Garlic bulb extract showed comparatively greater efficacy on promoting growth of two local varieties of groundnut. The fresh extracts of Allium sativum can be used to improve the vegetative growth of many plants (Block, 1985). Garlic extract contain antioxidant phytochemicals that prevent oxidant damage. These include unique water-soluble organosulfur compounds, lipid-soluble organosulfur components and flavonoids, notably allixin and selenium. Longterm extraction of garlic ages creating antioxidant properties by modifying unstable molecules with antioxidant activity, such as allicin, and increasing stable and highly bioavailable water-soluble organosulfur compounds, such as Sallylcysteine and S-allylmercaptocysteine (Borek, 2001). Onion and garlic are characterized by more polar compounds of phenolic and steroidal origin, often glycosilated, showing interesting pharmacological properties. These latter compounds, compared to the more studied thiosulfinates, (Lanzotti, 2006).

Cumin (Cuminum cyminum L.), a member of Apiaceae, is an annual plant which is originated from Egypt and East Mediterranean. The cumin fruits contain volatile oil $(2-5 \%)$ that imparts the characteristic aroma to the fruits. The yellow-coloured fresh oil contains cuminaldehyde and 2-p-menthadienals as its chief components (Behera et al., 2004). The fruits of $C$. cyminum L. are used as a traditional flavorings in a number of ethnic cuisines and food industries. Moreover, cumin oil shows a high antifungal activity against various pathogenic fungi, and effective high antibacterial activity. Therefore, it is also used as a fumigant or additive in the storage of foodstuffs. The medicinal component of the plant is oil which extracted from the ripe fruits. In folk medicine, cumin is used as a carminative for stomach disorders, diarrhea, and colic, as well as particularly in veterinary medicine ( $\mathrm{Li}$ and Jiang, 2004). The purpose of the present study was to use natural extracts from garlic and onion as a growth promoter of cumin.

\section{Materials and Methods}

The present experiment was carried out at the Horticulture Research Station of South El-Tahrer during (2011/2012) seasons. The experiment contained 12 treatments in addition to the control (using water) with three replicates. The statistical analysis design of the experiment was randomized complete block design. Each experimental plot was $\left(2 \times 6 \mathrm{~m}^{2}\right)$ with the spacing of $50 \mathrm{~cm}$ between rows and $25 \mathrm{~cm}$ between plants. Seeds were sown in the first week of November during both seasons. All treatments were sprayed three times at 30, 45 and 60 days after sowing. The garlic and onion extracts were prepared, hence, fresh mature were blended in distilled water $500 \mathrm{~g} / \mathrm{l}$, filtered then made up to three concentrations $(5,10$ and $15 \%)$. The essential oil extracts were prepared with 5,

Egypt. J. Hort. Vol. 41, No. 2 (2014) 
10 and 15\% in water and tween 20 (Kubota and Miyamuki, 1992). Data of plant growth (plant height, number of branches, number of umbels/ plant) and total seed yield (g/ plant) were taken and statistically analyzed (Snedecor and Cochran 1972). Identification of garlic and onion oils was carried out by GC/MS according to the method of Vargas et al. (2008) as shown in Tables 1 and 2.

TABLE 1. Chemical composition of garlic oil by GC/MS

\begin{tabular}{|l|c|}
\hline Components & $\mathbf{\%}$ \\
\hline 2-Vinyl-4H-1,3-dithiin & 2.65 \\
\hline 3,3'-Thiobis-1-Propene & 4.12 \\
\hline Methyl-trans-propenyl- disulfide & 0.43 \\
\hline Unknown & 1.54 \\
\hline 3-Prop-2-ene-1-sulfinyl) sulfanyl]prop-1-ene (allicin ) & 23.53 \\
\hline Diallyl disulfide & 21.98 \\
\hline Di-2-propenyl trisulfide & 6.31 \\
\hline Dimethyl -trisulfide & 17.43 \\
\hline Eugenol & 6.76 \\
\hline Unknown & 1.33 \\
\hline 3-Vinyl-[4H]-1,2-dithiin & 1.02 \\
\hline Diallyltetrasulphide & 2.65 \\
\hline Diallylpentasulfide & 0.32 \\
\hline Methyl allylpentasulfide & 0.13 \\
\hline B-caryophyilene & 3.93 \\
\hline Methyl allylhexasulfide & 5.87 \\
\hline
\end{tabular}

TABLE 2. Chemical composition of onion bulbs oil by GC/MS

\begin{tabular}{|l|c|}
\hline Components & \% \\
\hline Disulfide, 1-methylethyl propyl & 2.21 \\
\hline Methyl propyl disulfide & 3.65 \\
\hline Isopropyldithioisopropane & 13.12 \\
\hline S-benzyl phenylmethanethiosulfinate (allium thiosulfinate) & 23.56 \\
\hline Methyl propyl trisulfide & 11.54 \\
\hline Unknown & 0.95 \\
\hline Alkyl thiosulfnates & 21.34 \\
\hline 2-Tridecanone & 1.48 \\
\hline Allyl propyl disulphide & 15.65 \\
\hline 5-Methyl-2-octyl-(2H)-furan-3-one & 3.87 \\
\hline 3,5-Diethyl-1,2,4-Trithiolane & 0.97 \\
\hline 6,10,14-Trimethyl-2-Pentadecanone & 1.66 \\
\hline
\end{tabular}

Some chemical constituents of garlic cloves were Ca 1.363\%, Mg 1.23\%, Zn 66.5 ppm and Mn 94.4ppm (Nahed, 2009).

Essential oils were separated by water distillation according to the method of Guenther (1950). Fractionation and identification of cumin essential oil was executed by GC/MS schimadzu QP 5000 according to the method of Kan et al. (2007). The chemical composition of the treated cumin was performed. In this concern, protein (A.O.A.C., 1990), total carbohydrate, total soluble sugars (Dubois et al., 1956), total free amino acids (Jayaraman, 1985), total phenols 
content and total indoles (Daniel and George, 1972) and essential oil percentages were determined.

\section{Results and Discussion}

Effect of onion and garlic extracts on plant growth, production and chemical composition of cumin:

Plant growth

Data shown in Table 3 indicated that, all extracts (Onion and Garlic) had a significant effect in increasing all cumin growth parameters (plant height, branches number and umbels number) compared with the control. The highest plants $(41.50$ and $41.77 \mathrm{~cm})$ were produced with garlic water extract (at $15 \%)$ in the first and second seasons, respectively, while the shortest plants (34.24 and $28.00 \mathrm{~cm}$ ) were resulted in the control plants in the first and second seasons, respectively. On the other hand, the concentration of $10 \%$ onion water extract enhanced the other cumin growth parameters such as branches number and umbels number/plant compared with the other treatments and the control in both seasons.

TABLE 3. Effect of onion and garlic extracts on cumin growth parameters

\begin{tabular}{|l|c|c|c|c|c|c|c|}
\hline \multirow{2}{*}{ Treatments } & \multicolumn{3}{|c|}{ First season } & \multicolumn{3}{c|}{ Second season } \\
\cline { 3 - 8 } & & $\begin{array}{c}\text { Plant } \\
\text { height(cm) }\end{array}$ & $\begin{array}{c}\text { Number of } \\
\text { branches/ plant }\end{array}$ & $\begin{array}{c}\text { Number of } \\
\text { umbels/ plant }\end{array}$ & $\begin{array}{c}\text { Plant height } \\
\text { (cm) }\end{array}$ & $\begin{array}{c}\text { Number of } \\
\text { branches/ plant }\end{array}$ & $\begin{array}{c}\text { Number of } \\
\text { umbels /plant }\end{array}$ \\
\hline Control & 34.24 & 8.00 & 18.67 & 28.00 & 6.67 & 17.07 \\
\hline \multirow{3}{*}{$\begin{array}{l}\text { Onion } \\
\text { oil }\end{array}$} & $5 \%$ & 34.91 & 8.67 & 19.67 & 31.67 & 7.67 & 17.97 \\
\cline { 2 - 8 } & $10 \%$ & 36.09 & 9.67 & 24.67 & 33.67 & 8.67 & 23.67 \\
\cline { 2 - 8 } & $15 \%$ & 37.34 & 9.67 & 22.67 & 34.10 & 9.00 & 21.80 \\
\hline \multirow{3}{*}{$\begin{array}{l}\text { Garlic } \\
\text { oil }\end{array}$} & $5 \%$ & 35.34 & 10.00 & 21.00 & 32.73 & 9.33 & 21.27 \\
\cline { 2 - 8 } & $10 \%$ & 37.28 & 10.33 & 25.33 & 35.73 & 9.67 & 25.72 \\
\hline \multirow{2}{*}{$\begin{array}{l}\text { Onion } \\
\text { water } \\
\text { extract }\end{array}$} & $15 \%$ & 39.76 & 9.67 & 21.00 & 38.83 & 9.33 & 20.57 \\
\cline { 2 - 8 } & $10 \%$ & 37.27 & 10.00 & 25.67 & 35.90 & 10.00 & 25.93 \\
\hline \multirow{2}{*}{$\begin{array}{l}\text { Garlic } \\
\text { water } \\
\text { extract }\end{array}$} & $15 \%$ & 39.52 & 10.67 & 28.67 & 38.40 & 11.33 & 29.03 \\
\hline \multicolumn{2}{|c|}{ LSD at $(0.05)$} & 9.33 & 27.33 & 40.27 & 9.33 & 28.13 \\
\cline { 2 - 8 } & $10 \%$ & 37.67 & 10.00 & 23.33 & 36.73 & 9.67 & 22.57 \\
\hline
\end{tabular}

Seed yield

It is clear from the results in Table 4 that, all of the treatments produced higher yield than control during the two seasons. The highest total seed yield (2.99 and $3.31 \mathrm{~g} /$ plant) was obtained by spraying onion water extract at $10 \%$ in the first and second seasons, respectively, while the lowest yield (1.10 and 1.55 $\mathrm{g} / \mathrm{plant}$ ) were resulted in the control plants in the first and second seasons, respectively. 
TABLE 4. Seed yield of cumin as affected by spraying garlic and onion extracts

\begin{tabular}{|c|c|c|c|}
\hline \multirow[b]{2}{*}{ Treatments } & & First season & Second season \\
\hline & & $\begin{array}{l}\text { Total seed yield } \\
\text { (g/ plant) }\end{array}$ & $\begin{array}{l}\text { Total seed yield } \\
\text { (g/ plant) }\end{array}$ \\
\hline \multicolumn{2}{|l|}{ Control } & 1.10 & 1.55 \\
\hline \multirow{3}{*}{$\begin{array}{l}\text { Onion } \\
\text { Oil }\end{array}$} & $5 \%$ & 1.53 & 1.70 \\
\hline & $10 \%$ & 2.13 & 2.33 \\
\hline & $15 \%$ & 1.73 & 1.74 \\
\hline \multirow{3}{*}{$\begin{array}{l}\text { Garlic } \\
\text { Oil }\end{array}$} & $5 \%$ & 1.67 & 1.62 \\
\hline & $10 \%$ & 2.20 & 2.28 \\
\hline & $15 \%$ & 1.63 & 1.60 \\
\hline \multirow{3}{*}{ Onion water extract } & $5 \%$ & 2.33 & 2.71 \\
\hline & $10 \%$ & 2.99 & 3.31 \\
\hline & $15 \%$ & 2.63 & 2.90 \\
\hline \multirow{3}{*}{ Garlic water extract } & $5 \%$ & 2.03 & 2.28 \\
\hline & $10 \%$ & 1.90 & 1.86 \\
\hline & $15 \%$ & 1.43 & 1.59 \\
\hline \multicolumn{2}{|c|}{ LSD at $(0.05)$} & 0.07 & 0.16 \\
\hline
\end{tabular}

\section{Chemical composition}

The chemical composition of cumin seed as affected by spraying garlic and onion extracts are presented in Table 5. Generally, data revealed that garlic water extract at $10 \%$ resulted in the highest percentage of essential oil inboth seasons. Garlic water extract at $5 \%$ and $10 \%$ significantly increased the percentage of protein. In addition, the highest amino acid percentage in the first and second seasons was obtained by using $10 \%$ and $15 \%$ garlic water extract, respectively. Also, the concentration of garlic water extract at $5 \%$ gave the highest percentage of total carbohydrate in the first season, while, the same treatment at $10 \%$ resulted in the highest percentage of total carbohydrate in the second season.

The results also indicated that garlic water extract at 5\% and $10 \%$ significantly increased the percentage of total sugars and total phenols in both seasons. On the other hand, garlic oil at $10 \%$ and $15 \%$ significantly increased the percentage of total indoles in both seasons whereas the onion water extract at $15 \%$ significantly increased the percentage of total indoles in the second season only.

The obtained results are in agreement with those obtained by Chowdhury et al. (2007) and Botelho and Müller (2007). Also, Abd El-Rzek et al. (2011 and 2013) cleared that, spraying garlic extract had a positive effect on fruit physical and chemical characteristics, which improve the productivity and fruit quality. These effects were agreed with the results obtained by Ahmed et al. (2009) who reported that, fruits treated with garlic extract had the heaviest and largest fruits with the highest TSS. 
TABLE 5. Chemical Composition \% of cumin as affected by spraying garlic and onion extracts

\begin{tabular}{|c|c|c|c|c|c|c|c|c|}
\hline \multirow{2}{*}{\multicolumn{2}{|c|}{ Treatments }} & \multicolumn{7}{|c|}{ First season } \\
\hline & & $\begin{array}{c}\text { Essenti } \\
\text { al oil }\end{array}$ & Protein & $\begin{array}{c}\text { Amino } \\
\text { acids }\end{array}$ & Carbohydrate & $\begin{array}{c}\text { Total } \\
\text { sugars }\end{array}$ & $\begin{array}{c}\text { Total } \\
\text { phenols }\end{array}$ & $\begin{array}{c}\text { Total } \\
\text { indoles }\end{array}$ \\
\hline \multicolumn{2}{|c|}{ Control } & 5.4 & 8.469 & 1.693 & 37.218 & 12.677 & 0.668 & 0.0076 \\
\hline \multirow{3}{*}{$\begin{array}{c}\text { Onion } \\
\text { oil }\end{array}$} & $5 \%$ & 5.4 & 9.213 & 1.869 & 36.293 & 11.160 & 0.561 & 0.0070 \\
\hline & $10 \%$ & 5.7 & 8.708 & 1.534 & 41.772 & 7.915 & 0.605 & 0.0073 \\
\hline & $15 \%$ & 5.8 & 7.705 & 1.322 & 40.640 & 9.528 & 0.567 & 0.0073 \\
\hline \multirow{3}{*}{$\begin{array}{c}\text { Garlic } \\
\text { oil }\end{array}$} & $5 \%$ & 5.4 & 8.31 & 1.726 & 39.367 & 10.627 & 0.640 & 0.0067 \\
\hline & $10 \%$ & 5.4 & 8.550 & 1.407 & 39.336 & 9.443 & 0.666 & 0.0080 \\
\hline & $15 \%$ & 5.7 & 10.882 & 1.756 & 37.436 & 11.240 & 0.610 & 0.0080 \\
\hline \multirow{3}{*}{$\begin{array}{c}\text { Onion } \\
\text { water } \\
\text { extract }\end{array}$} & $5 \%$ & 5.9 & 8.394 & 2.172 & 34.851 & 8.707 & 0.640 & 0.0078 \\
\hline & $10 \%$ & 5.8 & 9.408 & 2.097 & 34.296 & 10.706 & 0.582 & 0.0070 \\
\hline & $15 \%$ & 5.6 & 10.155 & 2.215 & 33.141 & 11.532 & 0.650 & 0.0079 \\
\hline \multirow{3}{*}{$\begin{array}{c}\text { Garlic } \\
\text { water } \\
\text { extract }\end{array}$} & $5 \%$ & 6 & 13.431 & 2.310 & 42.519 & 13.757 & 0.711 & 0.0076 \\
\hline & $10 \%$ & 6.2 & 13.219 & 2.464 & 41.035 & 14.103 & 0.706 & 0.0064 \\
\hline & $15 \%$ & 5.6 & 10.259 & 2.349 & 38.804 & 7.919 & 0.631 & 0.0070 \\
\hline \multicolumn{2}{|c|}{ LSD at (0.05) } & -- & 0.477 & 0.409 & 0.716 & 0.736 & 0.057 & 0.0007 \\
\hline & & \multicolumn{7}{|c|}{ Second season } \\
\hline \multicolumn{2}{|c|}{ Control } & 5.2 & 8.084 & 1.659 & 37.701 & 12.020 & 0.659 & 0.0072 \\
\hline \multirow{3}{*}{$\begin{array}{c}\text { Onion } \\
\text { oil }\end{array}$} & $5 \%$ & 5.8 & 8.889 & 1.737 & 36.858 & 11.921 & 0.524 & 0.0072 \\
\hline & $10 \%$ & 6 & 8.441 & 1.693 & 42.272 & 8.006 & 0.605 & 0.0075 \\
\hline & $15 \%$ & 5.8 & 8.230 & 1.411 & 40.452 & 9.538 & 0.552 & 0.0074 \\
\hline \multirow{3}{*}{$\begin{array}{c}\text { Garlic } \\
\text { oil }\end{array}$} & $5 \%$ & 5.5 & 8.478 & 1.728 & 38.751 & 11.366 & 0.626 & 0.0065 \\
\hline & $10 \%$ & 5.5 & 8.159 & 1.378 & 38.966 & 9.511 & 0.700 & 0.0083 \\
\hline & $15 \%$ & 5.7 & 11.039 & 1.760 & 35.706 & 11.766 & 0.649 & 0.0082 \\
\hline \multirow{3}{*}{$\begin{array}{c}\text { Onion } \\
\text { water } \\
\text { extract }\end{array}$} & $5 \%$ & 5.8 & 8.746 & 2.398 & 34.696 & 8.780 & 0.632 & 0.0075 \\
\hline & $10 \%$ & 5.8 & 9.251 & 2.155 & 34.317 & 10.781 & 0.555 & 0.0070 \\
\hline & $15 \%$ & 5.7 & 10.237 & 2.148 & 33.672 & 11.246 & 0.634 & 0.0081 \\
\hline \multirow{3}{*}{$\begin{array}{c}\text { Garlic } \\
\text { Water } \\
\text { extract }\end{array}$} & $5 \%$ & 5.9 & 12.941 & 2.462 & 41.262 & 15.367 & 0.744 & 0.0073 \\
\hline & $10 \%$ & 6.3 & 13.082 & 2.477 & 43.404 & 15.558 & 0.712 & 0.0068 \\
\hline & $15 \%$ & 5.6 & 10.799 & 2.572 & 38.821 & 7.701 & 0.621 & 0.0070 \\
\hline \multicolumn{2}{|c|}{ LSD at $(0.05)$} & 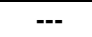 & 0.2848 & 0.3060 & 0.7232 & 0.5150 & 0.0461 & 0.0004 \\
\hline
\end{tabular}

Egypt. J. Hort. Vol. 41, No. 2 (2014) 
The physiological mechanisms of sulfur compounds action in growth and morphogenetic processes remain unknown. Some works to be considered concerning the effects of sulfur compounds leading to an inhibition of catalase (Khan et al., 1987). Furthermore, Shulman et al. (1986) declared that when the activity of the catalase decrease, an oxidative stress will be induced in several systems due to an increment of the hydrogen peroxide content.

\section{Volatile oil composition}

Data of volatile oil contents as influenced by spraying with onion and garlic extracts are presented in Table 6. Data clearly revealed that, cumin contained mainly cumin aldehyde, p-terpinen, phellandrene and p-mentha-14-dien-7-ol which represent $27.09,13.56,8.41$ and $8.32 \%$ of the oil. These results are in agreement with those reported by Li and Jiang (2004) and Kan et al. (2007). Data showed that, no changes occurred in chemical composition between control and treated plants with onion or garlic extracts.

TABLE 6. Chemical constituents and concentrations of compounds present in the cumin essential oil as affected by spraying garlic and onion extracts

\begin{tabular}{|c|c|c|c|}
\hline$\overbrace{\text { Compound }}^{\text {Concentration }}\left(\begin{array}{r}(\%) \\
\end{array}\right.$ & control & $\begin{array}{c}\text { Garlic water } \\
10 \% \text { extract }\end{array}$ & $\begin{array}{c}\text { Onion water } \\
\text { extract } 5 \%\end{array}$ \\
\hline alfa-Pinene & 1.23 & 1.25 & 1.31 \\
\hline Phellandrene & 8.41 & 8.26 & 8.55 \\
\hline Limonene & 3.72 & 3.50 & 3.86 \\
\hline p-Terpinen & 13.56 & 13.42 & 13.62 \\
\hline Terpinolene & 2.24 & 2.28 & 2.37 \\
\hline Carvotanacetone & 2.23 & 2.20 & 2.26 \\
\hline 1,8-Cineole & 1.5 & 1.50 & 1.48 \\
\hline Terpineol & 3.65 & 3.62 & 3.55 \\
\hline Cumin aldehyde & 27.09 & 27.01 & 26.97 \\
\hline p-Cymene & 6.98 & 6.14 & 6.91 \\
\hline Coumarin & 0.89 & 0.77 & 0.85 \\
\hline Caryophyllene oxide & 1.41 & 1.32 & 1.42 \\
\hline p-Mentha-1,4-dien-7-ol & 8.32 & 8.36 & 8.26 \\
\hline Thymol & 4.01 & 3.81 & 4.17 \\
\hline Cumin alcohol & 6.56 & 6.34 & 6.49 \\
\hline Hexadecanoic acid & 2.47 & 2.28 & 2.46 \\
\hline Geraniol & 3.08 & 3.17 & 3.02 \\
\hline Caryophyllene oxide & 2.65 & 2.35 & 2.45 \\
\hline
\end{tabular}

\section{General Discussion}

Garlic oil contains 3-[(Prop-2-ene-1-sulfinyl) sulfanyl prop-1-ene (allicin), diallyl disulfide and dimethyl-trisulfide (23.53, 21.98 and 17.43, respectively), these compounds had previously been reported on as derivatives of garlic (Kubota et al., 1999, 2000). On the other hand, onion oil contains S-benzyl phenyl methane thiosulfinate (allium thiosulfinate), alkyl thiosulfnates, and allyl propyl disulphide ( $23.56,21.34$ and 15.65, respectively). The obtained results 
are in partial agreement with those observed by Saleh et al. (2004) reported that, organosulfur compounds isolated from garlic by GC/MS are 3-vinyl-4H-1,2dithiin, 2-vinyl-4H-1,3-dithiin and isomers co-elution, and di-2-propenyl trisulfide. Also, Vargas-Arispuro et al. (2008) isolated and identified allicin and S-methyl cysteine sulfoxide (SMCSO) from garlic. Goldan et al. (1988) mentioned that, volatile sulfur compounds in onion such as carbondisulfide $\left(\mathrm{CS}_{2}\right)$, carbonylsulfide (COS), hydrogen sulfide $\left(\mathrm{H}_{2} \mathrm{~S}\right)$, methylmercaptan $\left(\mathrm{CH}_{3} \mathrm{SH}\right)$, and sulfur dioxide $\left(\mathrm{SO}_{2}\right)$ can be taken up by all onion parts

The chemistry of garlic is complex, with over 100 different compounds that contribute to its effects. The most important and unique feature is its high content of organosulfur substances (Block, 1985). Allicin is the main biologically active component of freshly crushed garlic (Allium sativum) cloves (Lawson et al., 1991). Members of the family Brassicaceae and of the taxon Allium (onion, garlic leek) are the most sulfur demanding plants and therefore excellent candidates for phyto-extraction (Ernst, 1998).

However, progress has been made in elucidating the implied routes in the regulation of sulphur in relation to the vegetative growth of plants (Hawkesford and De Kok, 2006). In the process of assimilation of sulphur by the plant, inorganic sulphur is fixed as cysteine after a process of reduction. Cysteine is the initial material for the production of reduced glutathione, which is responsible for detoxing cells through the elimination of free radicals and reactive species that accumulate during different types of stress. The sulphur molecules derived from garlic can be assimilated by the plant in the latent stage, it can favor the detoxification of the plant and promote bud breaking. At the same time, exogenous applications of reduced glutathione induced bud breaking when it was applied on buds of grapevines of (Vargas-Arispuro et al., 2008).

\section{References}

A.O.A.C. (1990) Association of Official Analytical Chemists. Washington DC, U.S.A.

Abd El-Rzek, E., Abd El-Migeed, M.M.M. and Abdel-Hamid, N. (2011) Effect of spraying garlic extract and olive oil on flowering behavior, yield and Fruit quality of 'Canino' apricot trees. American-Eurasian J. Agricultural \& Environmental Sci., 11 (6), 776-781.

Abd El-Rzek, E., Abd El-Migeed, M.M.M. and Abdel-Hamid, N. (2013) Response of 'Le Conte' pear trees to garlic extract and GA3 as budbreak dormancy agents. MiddleEast J of Sci. Res., 14 (11), 1407-1413.

Ahmed, M.A.M., Eman, A.A. and Abd El-Migeed, M.M.M. (2009) Effect of garlic extract and mineral oil spray on flowering, harvesting time, yield and fruit quality of peach (Prunus persica) trees cv. 'Florida prince'. Middle Eastern \& Russian J. Plant Sci. Biotechnology., 3, 53-57. 
Augusti, K.T. and Mathew, P.T. (1975) Effect of allicin on certain enzymes of liver after a short term feeding to normal rats. Experentia., 31(2), 148-149.

Augusti, K.T. (1996) Therapeutic values of onion (Allium cepa L.) and garlic (Allium sativum L.). Indian J. Experimental Biology., 34 (7), 634-640.

Behera, S., Nagarajan, S. and Rao, L.J.M. (2004) Microwave heating and conventional roasting of cumin seeds (Cuminum cyminum L.) and effect on chemical composition of volatiles. Food Chemistry., 87 (1), 25-29.

Block, E. (1985) The chemistry of garlic and onions. Sci. Amer., 252, 114-119.

Block, E., Naganathan, S., Putman, D. and Zhao, S.H. (1992) Allium chemistry: HPLC analysis of thiosulfinates from onion, garlic, wild garlic (ramsons), leek, scallion, shallot, elephant (great-headed) garlic, chive, and Chinese chive. Uniquely high allyl to methyl ratios in some garlic samples. Journal of Agriculture and Food Chemistry., 40, 2418-2430.

Borek, C. (2001) Antioxidant health effects of aged garlic extract. J. of Nutri., 131 (3s), 1010S-1015S.

Botelho, R.V. and Muller, M.M.L. (2007) Evaluation of garlic extract on bud dormancy release of 'Royal Gala' apple trees. Australian Journal of Experimental Agriculture, 47 (6), 738-741.

Chowdhury, M.N.A., Rahim, M.A. Khalequzzaman, K.M. Humauan, M.R. and Alam, M.M. (2007) Effect of plant extracts and time of application on incidence of anthracnose, yield and quality of mango. International Journal of Sustainable Crop Production, 2 (5), 59-68.

Daniel, H.D. and George, C.M. (1972) Peach seed dormancy in relation to indigenous inhibitors and applied growth substances. J. Amer. Soc. Hort. Sci., 97, 651-654.

Dimitri, C. and Oberholtzer, L. (2006) EU and U.S. organic markets face strong demand under different policies. Amber Waves. Economic Research Service USDA, 4, 12-19.

Dubois, M., Gilles, K.A., Hamilton, J.K., Rebers, P.A. and Smith, F. (1956) Colorimetric method for determination of sugars and related substances. Analytical Chemistry, 28, 350-356.

Ernst, W.H.O. (1998) Sulfur metabolism in higher plants: potential for phytoremediation. Biodegradation, 9, 311-318.

Goldan, P.D., Fall, R. Kuster, W.C. and Fehsenfield, F.C. (1988) Uptake of COS by growing vegetation: a major tropospheric sink. J. Geophysical Res., 93, 14186-14192.

Guenther, E. (1950) "The Essential Oils", Vol. 4. van Nostrand Co. New York, pp 213329.

Hawkesford, M.J. and De Kok, L.J. (2006) Managing sulphur metabolism in plants. $J$. of Plant, Cell \& Environment, 29 (3), 382-395.

Egypt. J. Hort. Vol. 41, No. 2 (2014) 
Jayaraman, J. (1985) Post Harvest Biological Control. Wiley: Eastern, New Delhi (India) Ltd.

Kan, Y., Kartal, M., Ozek, T., Aslan, S. and Baser, K.H.C. (2007) Composition of essential oil of Cuminum cyminum L. according to harvesting times. Turkish $\mathrm{J}$. Pharmaceutical Sci., 4, 25-29.

Khan A.A., Schuler, M.M. and Coppock, R.W. (1987) Inhibitory effects of various sulfur compounds on the activity of bovine erythrocyte enzymes. J. Toxicol Environ Health., 22 (4), 481-490.

Kortbech-Olesen, R. (2006) The United States market for organic food and beverages. International Trade Center Report. Available at http://www.intracen.org/ mds/sectors/ organic Accessed 2 March 2006.

Kubota, N. and Miyamuki, M. (1992) Breaking bud dormancy in grapevines with garlic paste. J. Amer. Soci. for Hort. Sci., 117(6), 898-901

Kubota, N., Matthews, M.A., Takahagi, T. and Kliewer, W.M. (2000) Bud break with garlic preparations. Effect of garlic preparations and of calcium and hydrogen cyanamides on budbreak of grapevines grown in greenhouses. Amer. J. Enology and Viti., 51, 409- 414.

Kubota, N., Yamane, Y., Toriu, K., Kawazu, K., Higuchi, T. and Nishimura, S. (1999) Identification of active substances in garlic responsible for breaking bud dormancy in grapevines. J. the Japanese Soc. for Hort. Sci., 68, 1111-1117.

Lanzotti, V. (2006) The analysis of onion and garlic. J. of Chromatography., 1112, 3-22.

Lawson, L.D., Wang, Z.J. and Hughes, B.G. (1991) Identification and HPLC quantitation of the sulfides and dialk(en)ylthiosulfinates in commercial garlic products. Planta Medica., 57 (4), 363-370.

Li, R. and Jiang, Z.T. (2004) Chemical composition of the essential oil of Cuminum cyminum L. from China. Flavour and Fragrance. J., 19, 311-313.

Nahed, S.A. (2009) Physiological studies on oenotherabiennis (Bio -fertilizer plant extracts) Ph.D. in Horticulture, Faculty of Agriculture, Moshtohor, Benha University

Randle, W.M., Block, E. Littlejohn, M.H. Putman, D. and Bussard, M.L. (1994) Onion (Allium cepa L.) thiosulfinates respond to increasing sulfur fertility. Journal Agricultural and Food Chemistry., 42, 2085-2088.

Saleh, A., Jan,W., Paulina, G. Lumir, O. and Valery, M. (2004) The use of the 'Cryogenic' GC/MS and on-column injection for study of organosulfur compounds of the Allium sativum. Journal of Food Composition and Analysis, 17, 235-245.

Shulman Y., Nir, G. and Lavee, S. (1986) Oxidative processes in bud dormancy and the use of hydrogen cyanamide in breaking dormancy. Acta Hort., 179, 141-148.

Egypt. J. Hort. Vol. 41, No. 2 (2014) 
Snedecor G.W. and Cochran, J. G. (1972) Review: "Statistical Methods", $6^{\text {th }}$ ed. by G.W. and W. G., Biometrics., 28 (4), 1153-115.

Vargas-Arispuro, I., Corrales-Maldonado, C. and Martynez-Tellez, M.A. (2008)

Compounds derived from garlic as bud induction agents in organic farming of table grape. Chilean J. Agricultural Res., 68, 94-101.

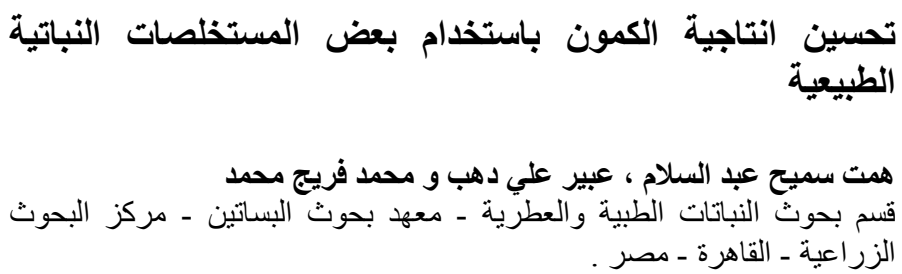

تمت دراسة تأثثر الزيوت الطبارة والمستخلصات المائية للثوم والبصل فى ثلاث

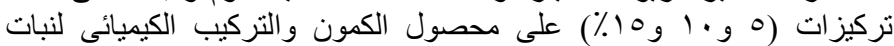

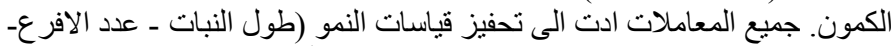

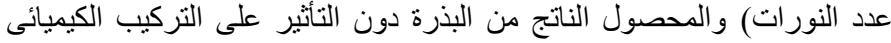

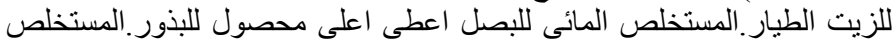

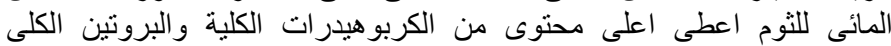

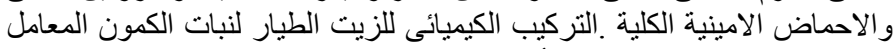

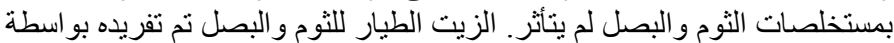

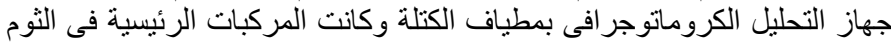

dimethyl -trisulfide g diallyldisulfide و Allicin

اما في البصل فكانت, allium thiosulfinat و و alkyl thiosulfnates

. propyl disulphide 